\title{
Rethinking Africa: Interview with Juma V. Mwapachu
}

Aidan Eyakuze, Programme Director (Tanzania), and Ahmed Salim, Programme Officer at the Regional Office of the Society for International Development, interview SID’s President Ambassador Juma V. Mwapachu.

AE: What does Africa's transformation mean for you?

JVM: Africa's transformation requires a radical departure from the philosophy of development. I think for too long since independence, Africa has been pursuing development as if it were something incremental. Therefore you find most of the social, economic technological strategies that have been adopted by African governments have had an impact even on the way the private sector has reacted and responded in addressing issues of poverty, disease and ignorance. It has been more or less a tactical approach to dealing with what seems to be the central problem of development. Transformation is a radical departure from business as usual. We need to address our structural bottlenecks and impediments and work towards ensuring our economies are better integrated and more competitive within the context of the global economy.

AE: Why do you think for 50 years roughly the African leadership across the continent has pursued a tactical path instead of forging a strategic radical change in its pursuit of development? What were the drivers behind this?

JVM: I think the answer partly lies in the ideologies that we embraced then. Those countries that were driven by political systems and economic philosophies guided by socialist principles did not seek transformation. They sought to achieve popular support of their masses and to move away from a colonial legacy, that seemed to be divisive along either race, wealth, tribe or religion. They were socioeconomic philosophies that were driven by the need to unify countries, rather than to bring about real economic transformation. I think one of the tragedies of Africa's change process is that this notion of unity, of empowerment has taken this long. It is only with the arrival of globalization that the vulnerability of our economies have been exposed and that leaders have come to realize that unless they rethink our approaches to social and economic development, we risk being swamped by external factors.

AE: What does this transformed Africa look like and how radically different might it be from what it is today or what it was in the past?

JVM: I think there are certain economic factors that one can look at, which probably were not given as much attention previously. For instance, infrastructure development - it is infrastructure that really opens up the economic spaces of any country and spurs internal growth, opens markets and builds up factors of competitiveness. If you 
read recent World Bank and African Development Bank reports you can see what underlies the African problematic is basically a poverty of infrastructure. So even 50 years after independence African countries and leaders are still pursuing the transformation of infrastructure because now they finally realize that it is key to bringing about the economic transformation they seek.

Secondly, Africa's economic potential has always relied on its agriculture. Here again there were plenty of symbolic approaches to transform agriculture and I think part of the reason is the romanticism with peasant agriculture. There has been this psychological fear that if you are going to open up the rural farm lands to any kind of commercial agriculture or improvement in the productivity of agriculture you are going to lose the peasant. The peasant constitutes the backbone of the African electorate and African leaders did not want to destabilize this major power base. There has been a lack of a forceful and radical transformative policy responses to changing the mode of agriculture, developing the necessary value chains and promoting agri-business as a critical factor in bringing about economic transformation.

Thirdly is education. Human capital is a major force for change and for transformation. But if you look over the years, you cannot help but wonder why there was a laxity in investing in the improvement of education as opposed to the increase in gross enrollments in primary and secondary schools. But now again suddenly, it has emerged that human capital is central to the quest for economic transformation: how to promote innovation, how to revive and embed science and technology in learning. Hence the urgency by our leaders to try and invest more in education.

But I think we have lost almost four decades. There is a body of literature out there - people like Calestous Juma have written a lot about this - that suggests that it is quite possible to leapfrog the science and technology achievements of the West as long as you have the right number of skilled people. Unfortunately we don't. I have recently reviewed the results from last year's Form Four national examinations in Tanzania - 86.7 percent of all students who took the mathematics exam failed. How do you build a core of your science and technology human capital, which is what drives economic transformation, with results like these? When you talk about value addition, or innovations into your manufacturing sector, bioengineering, nanotechnology and all the other technologies, which we need to transform our economies as well as the health of our people and improve food security then we cannot achieve this kind of transformation unless we do something about ensuring quality education, and particularly quality mathematics and science education in all primary and secondary schools.

AE: How about political transformation? Do you see any need for political and/or governance transformation? Or do you think we are there or just about there?

JVM: I think political transformation is one of the most important points of departure in terms of Africa realizing this great economic leap forward. Unfortunately political transformation has been reduced to institutions of democratic change or rather, the institution of five-year electoral processes under a multiparty political system. I don't think this is the kind of political transformation that we need.

I think the bigger issue is that of transformative and ethical leadership - a leadership that is close to the people and that communicates with the people. A leadership that is able to accept faults, prepared to back off from a particular line of development thinking. I don't think it necessarily means that you need to have a multi-party democratic system to be able to have a political leadership that is in line and in tune with the demands of economic transformation. We are now learning that in spite of instituting multi-party democracies, political pluralism will not work unless it is guided by deep-seated cultural values. We have numerous examples of this from West Africa, Zimbabwe, Madagascar, Lesotho, the Democratic Republic of the Congo and of course Kenya.

Political transformation fundamentally means that we are able to inculcate and embed those values that make tolerance and social cohesion work. A democracy will never work in a situation where there are gross inequalities, where there are strong ethnic divides and sensitivities. I think Africa has really suffered from the lack of values 


\section{Interview with Juma Mwapachu}

that support a democratic and pluralistic system. I can understand why China has left the issue of democratic change for later. I can understand why Rwanda President Paul Kagame, for example, is much more concerned about the socioeconomic transformation of his nation and of his people before allowing a hundred flowers to bloom in the country. Political transformation really requires that we understand our social system, the mindsets of our people and our historical background in terms of the social tensions that have ruled over the years and addressing those particular challenges before we simply graft onto our societies the western model of democracy.

AS: In February 2012, the East African Community (EAC) Secretary-General Richard Sezibera made a statement that was both hopeful and profoundly challenging, 'This is Africa's century, whether Africans own it or not'. Do you agree with that statement in light of the challenges we have regarding human capital?

JVM: Politically Africa has to take control of its own destiny. I think this is not just a statement of fact. It is a statement of reality. In as much globalization infers greater social and economic intercourse, we have to understand that Africa has to develop the capacity to deal with globalization.

When you take a broader look at how we have approached this question, you will find that we have tended to be very insular to the point where our regional integration efforts have actually suffered. Regional integration is seen by some as 'being swallowed by somebody else' in the short term, rather than looking at what the benefits of opening up to the rest of Africa and world might be from a longer-term perspective.

I think the point is that we are yet to enlighten ourselves enough about globalization and how we can relate and respond to it. My fear with the kind of resource nationalism that we are now seeing around Africa is that perhaps we are yet to understand that the whole idea around the opportunities for wealth creation and job creation is not removed from that intimate interface and intercourse with the rest of the world.

AS: So have we taken ownership of our own destiny or are external factors overwhelmingly influencing Africa's destiny?
JVM: I think we are yet to do so. If we go back to the point about the departure from a philosophy of development to that of transformation, I think one area that we have not looked closely at is the role of a developmental state. We have allowed our relationship with global markets and global forces to develop on a laissez faire basis. We have lost the grip of determining how our governments and economic players deal with this new global environment. I think it is important to reinstitute the role of the developmental state, not along socialist, ideological lines but a developmental state within a changed global economic landscape where it begins to determine the national interest.

AE: How is that different from state capitalism, which is what China and India are doing? Are they different?

JVM: They are different because a developmental state does not have to get into ownership. A developmental state is one that assures that the relationships between the national economy and outside players who come to deal with it follow fair rules and that the national interest is not just protected but also promoted. State capitalism is where the state goes for example into business, either directly or production sharing, which is an important element. If you look at the mining sector in Tanzania or Zambia for instance, we have shifted from the era of a 100 percent ownership to an era of 0 percent ownership. Some people feel that there was no need to go through this kind of a radical shift and that the government could still have retained a 30 percent or 40-49 percent stake and left 51 percent or majority shareholding to global companies.

AS: One of the advocates and supporters of a development state was the late Prime Minister Meles Zenawi of Ethiopia. In Ethiopia he is hailed as transforming the economy and being a visionary. What do you think of Prime Minister Zenawi and his legacy in Ethiopia and on the continent?

JVM: Meles Zenawi was to me the embodiment of a transformative leader - probably the only one of his kind. President Kagame of Rwanda would perhaps feature second. Zenawi was the African leader who had an economic vision for his country, who wanted to create a very strong self-reliant national economy, one that was heavily dependent 
on its own human capital. Whilst Ethiopia under Zenawi was one of the closest allies of the western economic centres as well as western capital, he represented the autonomous conscience that is not constant or common in the rest of Africa.

I think that the attribute of an autonomous conscience to me is really fundamental for an African leader who wants to use domestic resources (human and financial) to be the principal drivers of economic transformation. If you look at how Ethiopia has been able to liberate its peasants in terms of fair returns on their produce and crops, today Ethiopia offers a model worth emulating. Many African countries now send delegations to Addis to study the Ethiopian Commodity Exchange model. Commodity exchanges are of course nothing new, but Ethiopia was able to adapt it to local conditions and make it succeed in a way that it has not anywhere else in Africa.

AE: There is a huge amount of Afro-optimism compared to five years ago where there was a lot of Afro-pessimism. What do you think are some of the opportunities and the risks that come with this groundswell, of optimism about Africa?

JVM: A lot of this optimism can be found both in the West as well in the East - China, India and Korea. I think it is an optimism that is largely driven by three things:

First, consistent, stable and growing economic development. It is growth that is driven by Africa addressing the economic fundamentals of its economies, and in particular ensuring that the macroeconomic fundamentals are better managed. Normally the western world is very much concerned about shifting goalposts. When they see predictable economic environments and the emergence of legal and regulatory frameworks to support investments they begin to have a positive outlook towards those countries. I think over the last ten years the optimism in the West and East has really been that 'here is a new Africa that we can deal with business-wise'. There is now a predictable, stable macroeconomic environment. I think there are still concerns about the rule of law and we can come to that.

I think the second aspect, minus a few exceptions, and particularly for the western world, has 444 been the consolidation of democracy in Africa.
The kinds of political destabilization that used to happen in Africa have waned. Africa now has more stable political systems and processes and this is encouraging for the western world.

The third aspect - and this I think is a selfish one for the western world. Optimism is also based on the fact that Africa now suddenly seems to be full of natural resources, which the western world can exploit. I am calling it a selfish interest on the part of the western world because I think there can be some kind of a hyping up of Africa's potential. I think we sometimes do not mask this particular point when we look at this optimism of the West and countries like China and India in Africa. I think there is a selfish interest also from these countries in painting a rosy picture in Africa.

AS: Africa is now congratulated because of these growth rates. Are we living in an Africa bubble that going to burst in the future?

JVM: I don't think one can describe the steady growth that Africa has seen as in the last decade a bubble. There has been a great deal of improvement in the management of the governance of macroeconomic aggregates. There is a solid foundation for the economic growth that we have seen. I think the fear about a bubble is the sustainability of this growth. Africa is highly vulnerable to exogenous factors. Africa still largely exports commodities. Africa is not adding much value to its agriculture. Africa is yet to embrace agribusiness in any important economic sense. Africa is still dominantly dependent on natural resources. If you look at some of the high-growth countries in Africa you find that they are largely dependent on natural resources. Tanzania, Kenya and Uganda are moving in the same direction with the finds in oil and gas and uranium and of course natural resources are vulnerable to global price movements. Unless we build strong sustainable national economies that are rooted agriculture and its value-addition chains as well as industrialization that exploits our basic raw materials, we may find ourselves in a situation where the kind of economic growth that we have seen over the last decade is not sustainable.

AE: Looking at the East African Community where you were Secretary-General for five years, I 


\section{Interview with Juma Mwapachu}

want to ask you a specific question do you think the discovery of oil and gas will bring us closer as a community or will it tear us apart?

JVM: I think this question goes to the heart of the whole issue whether these natural resources will be a dividend or a curse. President Yoweri Museveni (Uganda) was consistently telling his colleagues, the EAC heads of state, that the oil and gas in Uganda was not just for Uganda but for the region. He was even urging the other EAC leaders to invest as countries in the exploitation of those resources and that these resources should be shared regionally. This is one perspective that one needs to be clear about: here is President Museveni, a highly integrationist leader in our region. But the other perspective is what do you really use the oil and gas resources for? If you're going to be like Angola where you do not want to participate in any regional activities because you have a lot of cash and believe that you can actually develop Angola without integrating with any other country, and that you can integrate yourself with the global economy and import whatever you want because of your wealth, then you are going to destroy regional integration.

The main purpose of regional integration is to move away from the 'beggar-thy-neighbour' syndrome. Maybe not all countries in the integration process will develop at the same pace, but you benefit from working together. If these resources can be applied towards developing regional infrastructure, providing the interconnectivities in energy, railways, roads and inland waterways so that the whole regional economic space for growth of small and mediumsized enterprises, border markets can be opened up and the cost of logistics reduced and competition improved, then the oil and gas resources have a regional benefit.

AE: The problem I believe with these discoveries and resource nationalism is that things get out of hand very quickly. The East African recently had a piece about the new discoveries of oil and gas contributing to new border skirmishes across the region. The recent border dispute between Tanzania and Malawi is another case in point. Do you think things will get out of hand or will cooler heads prevail within the EAC?
JVM: I don't know where the cooler heads are really going to emerge from within the EAC. I fear that the East African leadership is divided. You have very strong integrationists in it who would really be able to exercise cooler heads and who still believe that the future of East African economies very much hinges on how this whole geographical space can open up and markets allow to grow, people allowed to move freely across borders so that there is greater interplay in social and economic activities on the one hand.

On the other hand, there is a group of leaders within the EAC whom I think if they are to strike adequate natural resources might actually drift away from the community. But given our democratic setup, these leaders might not be in power for long and we may see a new breed of leaders emerge who may be more integrationist and who may see the meaning of the larger picture. East Africa cannot reinvent the wheel. Even with all the tribulations and troubles the European Union is going through, you still get the sense that Europe is saying that it can ill afford to separate. Here is a huge economic powerhouse of the world with almost 70 percent intraregional trade as a share of their total trade taking this stand, yet with East Africa intra-regional trade (IT) is only 11-12 percent. The scope for everybody's welfare and economic enrichment is so large. What is it that is really keeping these countries from getting closer? This is the paradox and I've found it very difficult to understand an African leadership that fails to appreciate the meaning of regional integration.

AS: We can't afford to drift apart but what we are seeing now are secessionist tendencies arising within the wider continent. The Economic Community of West African States (ECOWAS) has had a lot of problems with Mali and Côte d'Ivoire. In East Africa there is the issue of Mombasa and Zanzibar. Do you think these secessionist tendencies will deepen or will they just be a blip in our historical regional integration process?

JVM: I think the secessionist tendencies in West Africa are very much deemed secessionist from a regional integration or an African integration perspective. You can say that in Mali, the radical Islamic Tuareg want to go their way. I think one has to understand the underlying reasons 
behind it. When you have a fragile nationstate that lacks very strong heroic leadership, you will always have your separatist tendencies particularly in the context of the emergence of Islamic fundamentalism.

But the separatist tendencies at the East African coast as far as Mombasa is concerned I consider it a hype, a distorted description. I don't think it's a secessionist movement, there is a small segment of people at the coast that wants to forge a kind of separation but I don't see them garnering critical mass. As far as Zanzibar is concerned, I don't see Zanzibar as fitting a secessionist/separatist description at all because Zanzibar has to be seen as a sovereign state that joined another state.

The more fundamental questions for Africans to explore are the reasons for Africa pursuing an aspiration to integrate continentally. Why then do we have these separatist tendencies? Why is the Tanzanian union being jeopardized by the potential separation of Zanzibar? As far as Tanzania is concerned I believe that this is a matter that will find solution in the ongoing constitutional review process.

AE: Are Economic Partnership Agreements (EPAs) good for East Africa? President Benjamin Mkapa of Tanzania thinks not, neither does the former Governor of Nigeria's Central Bank, Professor Charles Soludo. Do you agree with their stance?

JVM: I think one has got to look at this question from a more balanced position. For a long time Africa has dealt with Europe within a system of general preferences. With the US, we now enjoy a similar system through the African Growth and Opportunity Act (AGOA). EPAs in themselves are nothing new. It is a new framework for a system of general preferences for the African, Caribbean and Pacific (ACP) countries. I think the new dimension that has cropped up through the EPAs is the return or benefit that the EU wants to enjoy. The previous system really just provided incentives to Africa, now they also want to share in that kind of an incentive system and this is where the principle challenge lies.

My biggest concern about EPAs is that they balkanize Africa. EPAs are not being negotiated 446 by Africa as political entity. They are not being negotiated with Africa even within the framework of regional economic communities, which one can interpret as an integration of nation states even though there is no political federation that ties them together. The signatory to EPAs are nationstates. The EU Commission signs on behalf of Europe; even though the EU is not a federation of states they are given so much political power when it comes to these types of negotiations so they can negotiate on behalf of the nation-state. But the Southern African Development Community (SADC), EAC and the Common Market for Eastern and Southern Africa (COMESA) cannot negotiate on behalf of the nation-states. They only provide the architecture and umbrella for them to negotiate but the signatories are the nation-states. By so doing, you are really balkanizing Africa because you are not enabling Africa to think and to act as a collective voice. And because the EPAs are tied to the World Trade Organization (WTO) rules and regulations where again it is only nation-states who are members, it really means that African countries now have got to relegate the very conditions and rules, which bring them together as integrated markets to the European Union.

Basically what EPAs are saying is that we are going to export/import to your countries duty free. You have to open up that customs union to the Europeans now.

AE: One could argue that that is our own fault that we are not negotiating as strongly as integrated countries. This is something that we as an East African Community can agree upon or are we prevented by WTO rules from negotiation as a bloc even if we do sign individually?

JVM: This is what the EAC has done and incidentally the EAC is the most integrated of African economic blocs as far as negotiating with EPA goes. This is why you have the South Commission and former President Mkapa worried as they see a lot of headway being made. SADC is split, COMESA, because of its mammoth size - they are unable to converge 26 countries to negotiate - and ECOWAS, because of the political skirmishes and difficulties in the region are unable to do so. The EAC has its focus right and will succeed in its galvanized position. 


\section{Interview with Juma Mwapachu}

The so-called galvanization has its difficulties because you have a Kenya - which is a middleincome country - negotiating with a least developed country and you really wonder whether Kenya should be part of this. Like South Africa it wants to be part of the SADC negotiations with EPAs when it has a separate agreement with the European Union (a development cooperation agreement) and then you have the Southern African Customs Union (SACU) within SADC saying that we have our own interests as a customs union. If SADC wants to negotiate it can negotiate on its own but those negotiations do not include SACU. You have members like Lesotho and Swaziland who rely on the SACU for up to 60 percent of their revenues now split as to whether they should negotiate with SADC (where they will benefit more) as opposed to negotiating under SACU. SACU is not prepared and South Africa is not prepared to negotiate as SACU because it still wants to have its dominant position.

AS: You mention how a transformation of Africa will require huge investment in infrastructure and education, that's one of the key tenets for development. We have two pan-African institutions that are very visible on the continent: the African Union (AU) and African Development Bank (AfDB). Which one of these is important at this stage and moving forward do you think the AfDB will supplant the AU as the most important institution on the continent in light of our discussion so far?

JVM:The two institutions, the AU and AfDB, were created for two different purposes. The AU is really the definer of Africa's political and economic development vision. It is like the grand master of how Africa can collectively move towards this grand vision of political and continental economic community. So they are really the strategic players in mobilizing and galvanizing its ethos and its thrust. The AU does not have resources to invest and I think therein lies its primary challenge it increasingly risks being seen primarily as a talk shop.

As Secretary-General of the EAC, I sensed a great deal of tension between the role of the AU as a grand project vis-a-vis the grassroots institu- tions - the regional economic communities (RECs), which enjoy grassroots interactions. They have grassroots economic space, which they can play around with and see visible and tangible results. There was a point in time before I became Secretary General of the EAC, where a previous Chair of the African Union Commission was marginalizing RECs up to a point where together with former Libyan President Gaddafi they were challenging the utility of the RECs and suggested they be disbanded in favour of having the $\mathrm{AU}$ being the vehicle for African integration.

The AfDB is supposed to be the marshaller, the mobilizer of resources to enable Africa to realize its grand vision. In my view the AfDB is the more powerful institution. It has better brains, is better organized and has the resource base to be able to provide a great deal of information and support to the AU even in terms of capacity building of the AU to undertake its work. The AfDB has a stronger relationship with RECs because that is where the action is and where the tangibility of regional integration can be seen. I think increasingly the AU is seen as an unnecessary ally (from the AfDB perspective).

AS: They do different and distinct things but could you envision where the RECs and grassroots, which essentially mean the people of Africa, will start looking to the AfDB for more vision and being what the AU is supposed to be? Do you see that tension arising already?

JVM: There is already tension because if you look at the way the AfDB organizes its annual conference, they are mini-summits and they bring together people who really matter as far as Africa's development is concerned. The AU is a political platform and people are more or less getting fedup with talk shops. They want to see results and when they go attend the AfDB meetings, they appreciate the way they are structured - they assemble together those interest groups critical to Africa's transformation - small and medium enterprise leaders, industrial innovators, educationists and so on. To me the AfDB is increasingly becoming the key African institution as far as the African transformation objectives are concerned. 
AE: In a globalizing world that is also increasingly uncertain, what is the glue that could bind Africans together in the twenty-first century?

JVM: I think the biggest challenge I see in Africa today quite honestly is that there is a lack of galvanizing African leadership that Africa enjoyed during those days of ideology of the African voice of the pan-African, Arab synergies and so on. Africa now lacks an African voice. I mean when it comes to the Syrian issue, Afghan issue or other issues like Libya you no longer see that galvanizing respected African voice.

AE: Why not?

JVM: I think there has been a leadership transition from the Nyerere's of Africa to a leadership that is now more nationally anchored and that sees globalization more in terms of the vulnerabilities of the nation-state. It does not seem to realize that these same vulnerabilities can be dampened through cross-integration with neighbouring states and the rest of Africa. I see it as a challenge of leadership quite honestly.

AE: How will we redefine the new African narrative and where will it come from? Will authors, intelligentsia or civil society drive it? The leaders we have referred to - Meles in Ethiopia and Kagame in Rwanda - have espoused nationalist than integrationist ideas.

JVM: I think the narrative will have to come from a new breed of leadership. I think the term 'leadership' in Africa has become too associated with political leadership. I think this leadership has to emerge from across the whole societal fabric. We need to harness the energy within the young people of Africa and use it to really redefine African hopes and generate the kind of narrative that will again create a groundswell of thinking.

Mind you, when it comes to music, I think we are seeing a great deal of fusion amongst African musicians. We are seeing in various facets of culture a great deal of cross-border intermingling and fusion and sharing of cultural performances. At the political level, maybe this new breed of African youth should be the centre of gravity for a renewal of the African narrative. A narrative that refocuses the African mindset to African unity and Africa's economic transformation as a continent.

AE: What are you most optimistic about?

JVM: In terms of Africa's future I'm more optimistic about the rise of the African youth; I think the African youth has great potential if even the supporting educational space needs to be further improved. I see a lot of suaveness, savviness, gusto and tempo for the African youth to move forward and I think Africa really needs to open up all the available spaces to enable its youth to realize the potential that they have, because I think they can be the principal transformers of Africa.

AS: What are you most worried about?

JVM: I'm very worried about the youth because I don't think they are allowed to fulfill their promise. There are various constraining conditions and unless these challenges are addressed, it is the same youth who could be the cause of Africa's instability and friction. 